\title{
Charlesworth on Philosophy and Religion
}

Charlesworth (2002) is a substantial reworking of Charlesworth (1972), occasioned by 'an extraordinary revolution ... in philosophy of religion' in the intervening period. According to Charlesworth, the scope of philosophy of religion had been vastly enlarged on the back of: (a) the long overdue recognition of the radical diversity of religions; (b) the invasion of the social sciences into the study of religious systems; and (c) the emergence of new-'postmodernist' - ways of doing philosophy of religion (1). (This page number-and all subsequent page numbers-refer to Charlesworth (2002).)

The main thesis of Charlesworth (2002) is that there are five approaches to philosophy of religion that constitute a grid on which most philosophies of religion can be located: (1) philosophy as religion; (2) philosophy as handmaid of religion; (3) philosophy as making room for faith; (4) philosophy as analysis of religious language; and (5) philosophy as postmodernist critique of the religious domain. Although the book ends with a brief discussion of the kinds of criteria to be invoked in an attempt to adjudicate between these five approaches, the chief aim of the book is to describe and analyse 'the main ways in which philosophy and religion have wrestled with each other in the ... two thousand years of Western thought' (176).

I begin with a brief summary of what Charlesworth has to say about the five approaches that he identifies, including his account of the strengths and weaknesses of each. I shall then turn to consider the merits of his 'grid' and his account of the nature and scope of philosophy, religion, and philosophy of religion.

\section{Philosophy as Religion}

According to Charlesworth, those who take the 'philosophy as religion' approach take the task of philosophy to be to lead sages to supra-mundane vision and illumination: religion is the culmination of philosophy (12). For Charlesworth, 'philosophy as religion' is an austerely contemplative approach to religion which is radically ahistorical, esoteric, abstract, theoretical, and committed to denial of any distinction between natural reason and supernatural truth (39). Charlesworth cites Plato, Aristotle, Plotinus, Pseudo-Dionysius, Al Razi, Al Farabi, Avicenna, Averroes, Leibniz, Spinoza, Hegel, Whitehead and de Chardin as exponents of this approach.

In Charlesworth's estimation, the primary complaint against the 'philosophy as religion' approach is the conception of the nature and scope of philosophy that goes along with it. While this approach has the advantage that it makes religion a rational enterprise that is worthy of human beings at their best and most human, it has the disadvantage that it presupposes a high metaphysical conception of philosophy that is open to various kinds of philosophical objections. But-according to Charlesworth-while philosophical positions are always tentative and revocable, religious assent typically implies absolute and irrevocable commitment (43). 


\section{Philosophy as Handmaid of Religion}

For Charlesworth, the 'philosophy as handmaid of religion' approach restricts philosophy to the twin tasks of (a) showing the 'non-impossibility' of the articles of faith; and (b) proving the 'preambles or presuppositions' of faith: roughly, that God exists and has some attributes that are accessible to our reason and understanding (79). On this approach, there are truths of revelation that cannot be established or grasped by merely philosophical inquiry but, nonetheless, religious faith depends upon philosophy for its 'defence' and for the 'justification of its preambles and presuppositions'. In contrast to the 'philosophy as religion' approach, the 'philosophy as handmaid of religion' approach allows room for an order of revelation and faith that transcends the order of philosophy and pure reason. Charlesworth cites Philo, Justin Martyr, Clement of Alexandria, Origen, Augustine, Abelard, Anselm, Bonaventure, Albertus Magnus, Alexander of Hales, Maimonides, Aquinas, Cajetan, John of St. Thomas, Garrigou-Lagrange, Gilson, Maritain, Mascall, and Farrer as proponents of the 'philosophy as handmaid of religion' approach.

In Charlesworth's estimation, while this approach is not quite so directly vulnerable to charges of 'religious intellectualism', it still involves a predominantly intellectualist or speculative view of religion. Moreover, since the understanding of the mysteries of faith involves at least the 'negative' employment of philosophical reason, the 'philosophy as handmaid of religion' approach is also open to charges of 'esotericism', 'ahistoricity', and 'impersonalism'. But, in Charlesworth's view, the most important objection to the 'philosophy as handmaid of religion' approach is that it makes religious belief dependent upon the viability of a specific conception of philosophy and upon the success of particular arguments that issue from that conception of philosophy: if philosophy cannot do the work of 'justifying the preambles and presuppositions of faith', then religious belief is embroiled in philosophical disputation (81).

\section{Philosophy as Making Room for Faith}

On Charlesworth's telling, the 'philosophy as making room for faith' approach meets the primary difficulties that face the 'philosophy as religion' and 'philosophy as handmaid of religion' approaches. In his view, the 'philosophy as making room for faith' approach: (a) makes religious faith independent of any direct reliance upon disputable philosophical premises; (b) guarantees the transcendence of the religious order; and (c) gives primacy to the practical mode of religious faith and its personal and 'inward' character (128). Charlesworth cites Tertullian, Peter Damian, Bernard of Clairvaux, Al Ghazali, Ockham, Nicholas of Autrecourt, Luther, Calvin, Pascal, Rousseau, [Hume], Kant, Kierkegaard, Mansell, Otto, Tillich, Barth, Kaufmann, and Cupitt as proponents of the 'philosophy as making room for faith' approach.

For Charlesworth, the primary difficulties that confront the 'philosophy as making room for faith' approach are (a) that we need to rely upon philosophical argument in order to draw the limits to 
reason that would make room for faith; (b) that it is hard to make sense of the idea that reason can be used to establish the bounds of reason; and (c) that the separation of the practical realm and the realm of faith from the speculative realm makes it impossible to give any account of the object of faith. In the end, the 'philosophy as making room for faith' approach effectively denies the autonomy and transcendence of faith (130).

\section{Philosophy as Analysis of Religious Language}

According to Charlesworth, the 'philosophy as analysis of religious language' approach is an attempt to elaborate a philosophy of religion without appeal to traditional metaphysics (133). Charlesworth's discussion takes in logical positivism, ordinary language philosophy, and broadly Wittgensteinian approaches to philosophy, citing Ayer, Braithwaite, Hare, Malcolm, Wittgenstein and Phillips.

Charlesworth makes piecemeal criticisms of the various 'philosophy as analysis of religious language' approaches. If he thinks that there is a more general critique to be made, perhaps it lies in his (implicit) suggestion that any view of philosophy of religion that takes it to be an essentially descriptive and non-explanatory inquiry will be severely compromised. If philosophy can have no transcendent function over and above the analysis of particular language games and forms of life, then philosophy can have nothing to say about the transcendent realm of the divine (148). In Charlesworth's eyes, those who suppose that there is a transcendent realm are bound to think that the 'philosophy as analysis of religious language' approach is hopelessly compromised by its minimalism and reductionism (153).

\section{Philosophy as Postmodernist Critique of the Religious Domain}

According to Charlesworth, the 'philosophy as postmodernist critique of the religious domain' is another attempt to elaborate a philosophy of religion without appeal to traditional metaphysics (155). On Charlesworth's account, postmodernism is an anti-foundationalist approach to philosophy which takes interpretative communities to be final points of reference in interpretative exercises, and claims that everything must be understood and interpreted within specific-and specifiedcontexts. In particular, for Charlesworth, postmodernists deny that there is - or can be-a metacontextual, God-like vantage point from which epistemological, ontological and metaphysical standpoints may be judged and justified. Charlesworth's discussion of postmodernism takes in a wide range of thinkers and writers: Nietzsche, Heidegger, Gadamer, Derrida, Foucault, Habermas, Rorty, Fish, Marion, Taylor, Guarino and Hart, among others.

Charlesworth is sceptical that there could be a postmodernist philosophy of religion, on analogy with the 'philosophy as religion', 'philosophy as handmaid of religion', and 'philosophy as making room for faith' approaches. Moreover, Charlesworth suspects that postmodernist critiques of metaphysically based religion and theology may be caught in 'fatal paradoxes'. While 
postmodernists object to 'totalising' claims about facts, truth, correctness, validity, and clarity, they make 'totalising' claims about contexts, situations, interpretations, justifications, hybridity, plurality, difference, and so forth. In Charlesworth's view, while postmodernism may have a valuable therapeutic effect, it is hard to see how it could lead to anything that deserved to be called a 'philosophy of religion' (172).

\section{Criteria for Judgment}

According to Charlesworth, any comparative assessment of the five approaches to philosophy of religion must make reference to two distinct sets of criteria. On the one hand, there are purely philosophical considerations arising from the conception of philosophy's nature and role on each of the five approaches to philosophy of religion. On the other hand, any philosophical account of religion that leads to systematic theological 'reductionism' is -in Charlesworth's eyes-clearly inadequate: a philosophy of religion that evacuates religion of any specific meaning of its own by reducing it to that which is not religion is inadequate as philosophy of religion (176).

On the first hand, Charlesworth suggests that (a) 'philosophy as religion' is viable only if some kind of transcendental metaphysics is possible; (b) 'philosophy as handmaid of religion' is viable only if philosophy can have a transcendental metaphysical role; (c) 'philosophy as making room for faith' is viable only if 'critical' philosophy is viable; (d) 'philosophy as analysis of religious language' is viable only if philosophy must have an 'analytic' or 'therapeutic' or 'anti-metaphysical' role; and (e) 'philosophy as postmodernist critique of the religious domain' is viable only if philosophy cannot have a metaphysical or foundationalist role (175).

On the second hand, Charlesworth admits that it is very difficult to say what 'reductionism' amounts to-though he does suggest that, perhaps, Hegel, Arnold, and Santayana make be taken as exemplary proponents of 'reductive' accounts of religion. But, even if there are clear cases, there are also hard cases: Charlesworth himself admits that it is hard to determine whether Kant, Plato, Plotinus, Spinoza, and Tillich are 'reductionists'. Recent discussions of 'reduction', 'supervenience', 'emergence' and the like strongly suggest that it is no easy task to achieve philosophical consensus about the proper understanding of these terms.

\section{Qualifications}

Before we turn to a critical assessment of Charlesworth's account of philosophy of religion, we need to note two disclaimers that Charlesworth introduces.

First, he observes that, 'for the purposes of this book', the religious domain is identified with 'the great monotheistic religions': Judaism, Christianity and Islam. To justify, or excuse, the lack of any attention paid to Hinduism, Buddhism, Jainism, Sikhism, Shintoism, Taoism, and so forth, Charlesworth merely observes that the philosophy of religion is very much a creation of Western 
philosophical and theological traditions: while there are analogous developments in Hinduism and Buddhism, philosophy has never had for them the autonomous status that it has enjoyed in the West (5).

Second, Charlesworth notes that he makes no detailed reference to feminist views on philosophy of religion. While he allows that there is a valuable feminist perspective on philosophy and theology, he denies that there can be either a feminist form of rationality or a feminist mode of doing philosophy and theology. In particular, he says that, in order to show to both women and men that there is a sui generis feminist mode of philosophical rationality, feminists would have to explain themselves in terms of commonly acknowledged canons of philosophical rationality which transcend gender differences (6). While Charlesworth does not explicitly address the broader issue, it seems plausible to suppose that he intends what he says about feminist views on philosophy of religion to extend to any other 'sub-group' views on philosophy of religion, ordered according to race, or ethnicity, or sexual orientation, or social class, or political orientation, or the like.

\section{Diversity of Religions}

It is curious that Charlesworth claims that long overdue recognition of the radical diversity of religions has contributed to the vast enlargement of scope of philosophy of religion, yet then -for the purposes of his book-goes on to identify 'the religious domain' with the Abrahamic religions. There is not the slightest shred of plausibility in the claim that recognition of the radical diversity of religions contributes significantly to the differences between Charlesworth (1972) and Charlesworth (2002). Of course, in making this observation, I do not mean to deny the correctness of the suggestion that western philosophy may be witnessing a long overdue move towards recognition of the radical diversity of religions. However, I would certainly want to add that, more than a decade after the publication of Charlesworth (2002), western philosophy is still broadly failing to make sufficiently serious engagement with the radical diversity of religions. One has only to consider-for example-the contents of handbooks and anthologies of philosophy of religion published by the major western presses to recognise that there has been little more than token engagement with the radical diversity of religions in the past decade.

Perhaps it is also worth noting that Charlesworth (2002) contains no references to the work of either John Hick or Ninian Smart. Hick's religious pluralism was explicitly and self-consciously framed as the outcome of serious [Christian] engagement with the radical diversity of religions; but it is not at all clear where Hick's religious pluralism should be located on Charlesworth's 'grid'. It may not be entirely outrageous to suggest that there are elements of each of 'philosophy as religion', 'philosophy as handmaid of religion', and 'philosophy as making room for faith' in Hick's interpretation of religion. Moreover, the field of religious studies - which received serious early support from both Hick and Smart-makes no contribution at all to the investigation that Charlesworth undertakes.

\section{Invasion of the Social Sciences}


It is hardly any less curious that Charlesworth claims that the 'invasion of the social sciences' anthropology, sociology, psychology and history-has contributed to the vast enlargement of scope of philosophy of religion, yet (a) fails to make substantial use of any materials from anthropology, sociology, psychology and history; and (b) more or less makes no mention of works in these fields, except in footnotes to the paragraph in which he claims that there has been an invasion of the social sciences in the study of religion. There is not the slightest shred of plausibility in the claim that recognition of 'the invasion of the social sciences' contributes significantly to the differences between Charlesworth (1972) and Charlesworth (2002). Nonetheless, in this case, it seems to me to be clearly true (a) that the social sciences-including the cognitive sciences-are having a steadily increasing degree of influence in philosophy of religion; and (b) that experimental philosophy, in its application to philosophy of religion, has introduced some of the methods of the social sciences into the practice of philosophy of religion.

On my reckoning, there are only six people who might plausibly be classified as social scientists who are mentioned by Charlesworth. None of the six-Durkheim, Evans-Pritchard, Freud, Geertz, LeviStrauss and Weber-is mentioned more than once, and none of them is paid substantive attention. Moreover, fundamental questions that have caused serious concern for social scientists-e.g. whether the idea that there is such a thing as religion is merely a Western conceit-are not taken up in Charlesworth's investigation.

\section{Charlesworth's Project}

Although Charlesworth claims that his study attempts to display the various basic ways in which philosophy has come to terms with the religious domain as defined by the great monotheistic traditions in the West and the Middle East (4), it is clear that this is not an accurate characterisation of what his study actually does. While-as I shall argue later-this is also not right, it seems to me that it would at least be closer to the truth to say that what his study attempts to display is the basic ways in which philosophers who view themselves as participants in-or fellow travellers withmonotheistic religions have conceived of the relationship between their philosophical beliefs and their religious beliefs. In particular, it seems at least initially plausible to say that 'philosophy as religion', 'philosophy as handmaid of religion', and 'philosophy as making room for faith' are all families of ways in which philosophers who view themselves as participants in-or fellow travellers with-monotheistic religions have conceived of the relationship between their philosophical beliefs and their religious beliefs.

'Philosophy as religion' is clearly a minority view-if represented at all-among Christians, Muslims and Jews who are serious practitioners of their religions. Many of the monotheists whom Charlesworth mentions under this head-Plato, Aristotle, Plotinus-were not members of an Abrahamic faith; and many of those who were nominally members of Abrahamic faiths-Leibniz, Spinoza, Hegel-had marginal standing within their faiths, and were widely regarded as heretics, or 
worse. On even the most casual consideration, there is evident difficulty for 'people of the book' in accepting 'philosophy as religion'.

If we set aside 'philosophy as religion', then the serious options that Charlesworth provides for Abrahamic philosophers of religion are 'philosophy as handmaid of religion' and 'philosophy as making room for faith'. Charlesworth's standard bearer for 'philosophy as handmaid of religion' is Aquinas; and his standard bearers for 'philosophy as making room for faith' are Kant and Kierkegaard. Interestingly, Charlesworth classifies Plantinga as a 'neo-Thomist' (5), but also acknowledges that Plantinga delineates a theory of knowledge and methodology sympathetic to [the 'philosophy making room for faith' approach of] Lutheran and Calvinist theology (149). The lesson that I am inclined to draw at this point is that Charlesworth's 'philosophy as handmaid of religion' / 'philosophy as making room for faith' dichotomy does not provide a very useful grid for classifying ways in which Abrahamic philosophers of religion think about the relationship between philosophy and religion.

I am inclined to think that 'philosophy as analysis of religious language' and 'philosophy as postmodernist critique of the religious domain' are unlikely to be attractive ways for Abrahamic philosophers of religion to think about the relationship between philosophy and religion. This is particularly clear in the case of 'philosophy as analysis of religious language': it is plainly worth noting that the philosophers that Charlesworth cites under this label are almost all atheists or irreligionists. Moreover, while it is clearly true that many Abrahamic philosophers of religion selfidentify as postmodernists, it is far from clear that those Abrahamic philosophers of religion are not also appropriately classified using one or both of the 'philosophy as handmaid of religion' and 'philosophy as making room for faith' labels. Philosophy, as religion, is given to many kinds of syncretism.

\section{Philosophy, Religion, and Worldview}

If we think that Charlesworth's 'philosophy as handmaid of religion' / 'philosophy as making room for faith' dichotomy does not provide a sufficiently fine-grained grid for classifying ways in which Abrahamic philosophers of religion think about the relationship between philosophy and religion, we might suppose that there is a more useful grid that we could put in its place. Furthermore, we may suppose that it remains a question to be answered whether Charlesworth's preliminary investigations provide a useful resource for such an undertaking.

Of course, not all philosophers of religion are Abrahamic philosophers of religion. Before we turn to consider the ways in which Abrahamic philosophers of religion think about the relationship between philosophy and religion, it will be profitable to think about the ways in which philosophers of religion think about the relationship between philosophy and religion. And, in order to approach that topic, we first need to consider the ways in which philosophers of religion think about philosophy, and the ways in which philosophers of religion think about religion.

There are many different ways of thinking about philosophy. Some philosophers think of philosophy primarily as an activity; some philosophers think of philosophy primarily as a way of life; some 
philosophers think of philosophy primarily as a systematic body of doctrines. I think that philosophy is primarily a domain of inquiry: philosophy is the discipline that addresses questions for which we do not yet know how to produce-and perhaps cannot even imagine how to produce-agreed answers using the methods of other disciplines. A consequence of my way of thinking about philosophy is that, for almost all other disciplines, there are borderline questions for which it is not currently clear whether those questions will, in time, be given agreed answers using what will then be established methods of those disciplines: for almost all disciplines, there is the sub-field of philosophy that is the philosophy of that discipline. Where a subject matter is taken up in a range of disciplines, the philosophy of that subject matter may well take in borderline questions from a range of disciplines. I say that this is how it is with philosophy of religion; there are no agreed answers to the questions addressed in philosophy of religion, and no agreed methods for resolving disagreements about the answers to these questions in relevant related disciplines: history, sociology, religious studies, and so forth.

There are many different ways of thinking about religion. Some philosophers have supposed that there is no such thing as religion: the concept of 'religion' is a Western construct whose employment serves only to advance and protect Western economic and political interests. Some philosophers have supposed that there are no interesting generalisations that can be made about religion: the concept of 'religion' is a family resemblance concept that resists informative analysis or definition. Some philosophers have supposed that their own religion is the one true religion, and that 'religion' can be satisfactorily defined in terms of that one true religion. I think that religions are, very roughly, forms of social organisation that regulate passionate, communal displays of costly commitments to non-natural agents and/or costly attempts to overcome non-natural superstructures of reality, thereby providing mastery of people's existential anxieties about death, deception, disease, catastrophe, pain, loneliness, injustice, want, loss, and the like. Religions have many dimensions: symbols, creeds, scriptures, sacraments, rituals, sharia, music, sacred buildings, sacred places, institutions, populations, histories, theoretical interpretations, and so forth. However, one thing that is central to religions is the provision of worldviews: accounts of the world and our place within it that aspire to a certain kind of comprehensiveness and fundamentality.

Given my characterization of philosophy and religion, it should come as no surprise to be told that I think that one of the central questions for philosophy of religion is the articulation, evaluation, and comparative assessment of worldviews. Since not all worldviews are religious worldviews, this central question is not merely a question for philosophy of religion. However, because religious worldviews are worldviews, the question is one of central significance for philosophy of religion.

There are various conceivable outcomes for philosophical investigation of worldviews. Philosophical investigation might suggest that the best worldviews that we have are religious worldviews. Philosophical investigation might suggest that the best worldviews that we have all belong to a particular religion. Philosophical investigation might suggest that the best worldviews that we have are non-religious-naturalistic, humanistic-worldviews. Philosophical investigation might make no suggestions about which are the best among currently accepted worldviews. Philosophical investigation might suggest only that there are many kinds of best worldviews, including some that are religious and some that are non-religious. Philosophical investigation of worldviews might turn out to be utterly intractable or otherwise entirely unable to secure any kind of expert agreement on the ranking of worldviews. 


\section{An Alternative Grid}

There are many views that Abrahamic philosophers of religion take on the outcome of philosophical investigation of worldviews. Some think that philosophical investigation demonstrates the superiority of particular Abrahamic worldviews to all other worldviews. Some think that philosophical investigation demonstrates the non-inferiority of particular Abrahamic worldviews to all other worldviews. Some think that philosophical investigation is inconclusive: given merely philosophical investigation, we are left in the dark about the relative merits of best worldviews. Some think that philosophical investigation appears to demonstrate the non-superiority of any Abrahamic worldviews to all competing-naturalistic, humanistic-worldviews. Some think that philosophical investigation appears to demonstrate the inferiority of all Abrahamic worldviews to competing-naturalistic, humanistic-worldviews.

Philosophical investigation of worldviews recognises many dimensions for assessment: etiological, methodological, ontological, epistemological, axiological, normative, explanatory, descriptive, and so forth. Since it is unclear how to weigh these dimensions, it seems plausible to suppose (a) that those who think that the superiority of some worldviews can be demonstrated maintain that it can be demonstrated that some worldviews are superior to all other worldviews on every one of the dimensions of assessment; and (b) that those who think that the non-inferiority of some worldviews can be demonstrated maintain that it can be demonstrated that some worldviews at least break even with all other worldviews on every one of the dimensions of assessment.

Those who think that philosophical investigation demonstrates the superiority of particular Abrahamic worldviews to all other worldviews appear not to leave any crucial role for faith when it comes to acceptance of worldview. After all, if a particular Abrahamic worldview is demonstrably superior to all other worldviews, then any competent person will adopt that worldview upon being provided with a suitable demonstration. While it might be true that one could accept the Abrahamic worldview in question merely on the basis of faith, it is not clear that this could be doxastically virtuous in circumstances in which a demonstration of that worldview is available to you.

Those who think that philosophical investigation demonstrates the non-inferiority of particular Abrahamic worldviews to all other worldviews and those who think that-given merely philosophical investigation-we are left in the dark about the relative merits of best worldviews may appear to leave a crucial role for faith when it comes to acceptance of worldview. For, given that philosophy does not provide decisive reasons to favour one worldview over all others, it may appear that the only consideration that can then justify the acceptance of one worldview rather than some other must be something like faith. However, there is at least room for suspicion that what is required here bears only a very loose resemblance to religious faith; after all, for example, 'methodological conservatism' is not typically regarded as being very much like religious faith.

Those who think that philosophical investigation appears to demonstrate the inferiority of all Abrahamic worldviews to competing-naturalistic, humanistic-worldviews may also appear to 
leave a crucial role for faith when it comes to acceptance of worldview. However, on the one hand, if you are presented with a demonstration of the inferiority of all Abrahamic worldviews to competing worldviews, and if you recognise that you have indeed been presented with such a demonstration, then it cannot be doxastically virtuous for you to continue to accept an Abrahamic worldview. And if, when presented with a demonstration of the inferiority of all Abrahamic worldviews to competingnaturalistic, humanistic-worldviews, you merely fail to recognise that it is a demonstration of the inferiority of all Abrahamic worldviews to competing worldviews, then-setting aside questions about the culpability of your failure to recognise that you have been presented with a demonstration of the inferiority of all Abrahamic worldviews to competing worldviews-there is no further role for faith to play in your continuing to espouse an Abrahamic worldview. Moreover, on the other hand, if you are presented with what merely purports to be a demonstration of the inferiority of all Abrahamic worldviews to competing worldviews, but you mistakenly suppose that it is indeed a demonstration of the inferiority of all Abrahamic worldviews to competing worldviews, then it cannot be doxastically virtuous for you to continue to accept an Abrahamic worldview, quite apart from any considerations about the virtues of faith. And if, when presented with what merely purports to be a demonstration of the inferiority of all Abrahamic worldviews to competing worldviews, you correctly identify that it is not a demonstration of the inferiority of all Abrahamic worldviews to competing worldviews, then there is no role left for faith to play in the maintenance of your Abrahamic worldview.

If we take seriously the diversity of religions and the evidence from the social sciences, then, I think, we must take seriously the idea that it is part of the project of philosophy of religion to articulate, compare, and assess religious and non-religious worldviews. But, if we do take seriously the idea that it is part of the project of philosophy of religion to articulate, compare, and assess religious and non-religious worldviews, then we cannot suppose that Charlesworth's investigations shed much light on the relationships that hold between philosophy, religion and philosophy of religion. 'Philosophy as religion', 'philosophy as handmaid of religion', and 'philosophy as making room for faith', are simply not appropriate ways of thinking about the project of articulating, comparing and assessing religious and non-religious worldviews.

\section{Residual Questions}

The discussion to this point leaves many questions unanswered. In particular, it might be suggested that, even if I am right in claiming that Charlesworth's investigations do not shed much light on the relationships that hold between philosophy, religion and philosophy of religion, it may still be the case that Charlesworth's investigations illuminate the basic ways in which philosophers who view themselves as participants in-or fellow travellers with-monotheistic religions have conceived of the relationship between their philosophical beliefs and their religious beliefs. However, as I foreshadowed some pages back, I do not think that it is correct to claim that Charlesworth's investigations do illuminate the basic ways in which philosophers who view themselves as participants in-or fellow travellers with-monotheistic religions have conceived of the relationship between their philosophical beliefs and their religious beliefs. 
I am happy enough to accept that Charlesworth's investigations do illuminate the basic ways in which philosophers who view themselves as participants in-or fellow travellers with-monotheistic religions have conceived of the relationship between what they took to be their philosophical beliefs and their religious beliefs, given their understanding of the nature and source of their philosophical beliefs and religious beliefs. However, it is one question what people take to be their philosophical and religious beliefs, given their understanding of the nature and source of philosophical and religious beliefs; it is quite a different question what are the philosophical and religious beliefs of those people, given our understanding of the nature and source of philosophical and religious beliefs.

Consider Aquinas. He thinks that some of his beliefs-his 'religious beliefs'-are revealed to him by God, via scripture, or religious experience, or the like; and he thinks that some of his beliefs - his 'philosophical beliefs' - are such that he arrived at them through the use of human reason, without any further divine assistance. For Aquinas, unaided reason does not deliver the belief that the world is only finitely old; so, he thinks, his belief that the world is only finitely old is a 'religious' belief but not a 'philosophical' belief. On the other hand, for Aquinas, unaided reason delivers the beliefconfirmed by scripture-that there is an unmoved mover; so, he thinks, his belief that there is an unmoved mover is both a 'religious' belief and a 'philosophical' belief. By his own lights - given his further belief that reason cannot contradict revelation-Aquinas could see himself as a poster boy for 'philosophy as handmaid of religion'. But, by our lights, given how little effort Aquinas puts into systematically articulating, evaluating and comparing non-religious alternatives to his own worldview, we are in no position to judge what he would have said had he undertaken a systematic evaluation of a wide compass of worldviews.

The critical observation that we have just made about Aquinas - that he does not pay sufficiently serious attention to non-religious worldviews - applies in even greater measure to Charlesworth himself. Ancient atomism, modern materialism, and contemporary naturalism have all thrown up non-religious worldviews that must be taken into account in any serious reckoning of religious worldviews. To suppose that the views of the relationship between philosophy and religion of proponents of ancient atomism, modern materialism, or contemporary naturalism might be captured by one of 'philosophy as religion', 'philosophy as handmaid of religion', and 'philosophy as making room for faith' is transparently implausible. Sensitivity to the radical diversity of religions should go hand in hand with sensitivity to the radical diversity of religious and non-religious worldviews; but no one with the latter sensitivity can suppose that Charlesworth's 'grid' is fit for its self-professed intended purpose.

While I don't have space left to do full justice to this issue, I should also say something concerning Charlesworth's remarks about feminist perspectives on philosophy of religion. Given that worldviews are accounts of the world and our place within it that aspire to a certain kind of comprehensiveness and fundamentality, it seems to me that it makes perfect sense to identify a sub-class of feminist worldviews: a sub-class of worldviews whose ideology draws upon various kinds of feminist analyses. Moreover, I think, the same can be said about worldviews whose ideology draws upon analyses ordered according to race, or ethnicity, or sexual orientation, or social class, or political orientation, or the like. But, if there can be feminist worldviews-both religious and non-religious - then those worldviews cannot be ignored in a philosophy of religion that aspires to give a comprehensive comparative assessment of worldviews. 


\section{Concluding Remarks}

Charlesworth (2002) is a work of impressive scholarship and erudition. It demonstrates intimate acquaintance with many who might reasonably be pigeon-holed under the 'philosophy as religion', 'philosophy as handmaid of religion', 'philosophy as making room for faith banners', 'philosophy as the analysis of religious language' or 'philosophy as postmodernist critique of the religious domain'. However, in my view, the work has serious shortcomings, due in much larger part to what it overlooks than to what it includes. When we consider the truly radical diversity of religious and nonreligious worldviews - as well as the truly radical diversity of conceptions of philosophy and religion-it ceases to be plausible to suppose that the 'grid' that Charlesworth provides is useful for neophytes, established scholars, or anyone in between.

\section{References}

Charlesworth, M. (1972) Philosophy of Religion: The Historic Approaches New York: Herder and Herder

Charlesworth, M. (2002) Philosophy and Religion: From Plato to Postmodernism Oxford: One World 